\title{
Fuzzy Language Processing in Translation of Literature: A Case Study of Dr. Zha's Diary of Fighting the COVID-19
}

\author{
Aijun Yang \\ School of Applied Foreign Languages, Zhejiang Yuexiu University, Shaoxing, Zhejiang, 312000, China
}

\begin{abstract}
Aesthetics is a subject focusing on studying the nature and significance of beauty (including beauty in language, art, literature, etc.). Moreover, the development of aesthetics, within the broader context of literary systems, is of significant importance. Chinese Literature (which in essence differs from that of English Literature) expresses beauty using its unique ways, especially with the employment of fuzzy language (also known as "vague language"). By including a certain degree of "fuzziness", Chinese Literature grants readers room fir imagination. However, the process of translating Chinese fuzzy language into other languages is not an easy feat to accomplish. Such translations can, to a large extent, seriously affect the original meaning of the text. To explore proper ways of "fuzzy language" translation, this paper ventures to analyze the processing methods used in the translated work "Dr. Zha's Diary of Fighting the COVID-19". Categorizing vague language into three perspectives, namely, semantic vagueness, cultural vagueness and rhetorical vagueness, the paper analyzes the way to tackle fuzzy language with 16 detailed cases. Based on the case analyses, the paper proposes that the proper translation of fuzzy language in literature will be more conducive for readers to appreciate the works and helps to improve the translation quality. By exploring the ways of processing fuzzy language, this paper hopes to bring some suggestions and inspiration to other researchers.
\end{abstract}

Index Terms - fuzzy language, Dr. Zha's Diary of Fighting the COVID-19, translation strategy

\section{INTRODUCTION}

Baker \& Saldanha (2020) espouse that, "literary texts enjoy high social prestige; they typically aim to provoke emotions and/or entertain rather than influence or inform; they have no real-world truth-value: they are judged as fictional, whether fact based or not; they may demand extra reading or listening effort by audiences, but deliver messages or experiences beyond the commonplace. In addition, their meanings may be ambiguous and/or indeterminable, and they may use poetic language that privileges language form, as in the case of wordplay or rhyme (Jakobson 1960/1988); they are characterized by heteroglossia, depicting different voices with different viewpoints". "Extra reading or listening effort" indicates that the interpretation of the text requires some additional effort by audiences. For translators, the ambiguity and in determinability found within these literary works can lead to a big challenge - the proper translation of fuzzy language.

It is widely accepted that the quality of literary translation on the one hand is determined by the quality of the works themselves and on the other it depends on whether the aesthetic elements in the original works can be fully reproduced in the process of translation. Thus, aesthetic analysis of literary works and the reproduction of aesthetic elements in the original works are the top priorities in translation. The beauty of literary works is mostly valued on the aesthetic expression of language, which includes the use of rhetoric, the listing of parallelism and the rhyming of letters, which we define as the morphological beauty of physical existence. Contrary to these aesthetic representational elements, there are some non-representational elements, such as imagination, emotion, and artistic conception. There are also crucial factors that constitute the aesthetics of literary works, but these factors are intangible and cannot be measured quantitatively, so they are expressed in vague language. Research has proven that the fuzziness of literature is defined by the fuzzy factors of the aesthetic composition of literary works. In the process of literary creation authors take language as the foundation, use divergent thinking to imagine and reason, and use language tools to endow imagination with reality and shape the characters' image and background environment. Therefore, it can be inferred that the fuzziness of language in the original works will directly lead to the fuzziness of translated works, which will cause trouble for target language reader to understand the original author's writing purpose. Therefore, this paper will venture to explore proper ways to handle fuzzy language with the case of Dr. Zha's Diary of Fighting the COVID-19.

\section{Connotation And CATEGorization of FuZzy LANGUage}

\section{A. Connotation of Fuzzy Language}

Fuzziness is an inborn feature of literary language which widely exists in phonetics, grammar and semantics, moreover fuzzy language in most cases can enhance the beauty of literary texts. But in literary translation, the 
translation of fuzzy language is often a big challenge and an important part, which involves not only the translator's language coding ability but also their cognitive ability. Since fuzzy language is so significant and difficult to handle, researchers have been attaching special importance to it. Peirce (1902) understands it this way: "when there exist several possible states of things", although the speaker has contemplated these possible states, he still cannot be sure whether these states are allowed or excluded by a proposition. Then, we say this proposition is fuzzy". He defines fuzzy language from the perspective of the addresser and arouses other researchers to focus on this topic. Based on his efforts, Zadeh (1965), a key figure in the field of fuzzy language, holds that most human cognition and human activity interacting with the outside world involves "fuzzy sets" rather than classical sets, and the "fuzzy sets" have "unsharp boundaries" and he also indicates that, fuzzy set is a class of objects with a continuum of grades of membership. Such a set is characterized by a membership (characteristic) function which assigns to each object a grade of membership ranging between zero and one.

Ullmann (1962), a Hungarian linguist, explores the formation of fuzziness from semantics and points out an important aspect of vagueness throughout his work Semantics: An Introduction to the Science of Meaning. If one looks closely at this vagueness, they will discover that the term in itself is rather vague and ambiguous. The condition it refers to is not a uniform feature but has many aspects and may result from a variety of causes. Channel (2000) in "Vague Language" indicates that for a general approach to theories of language and communication, there are two significant implications of research into the use of vague language. Firstly, vague language is very frequent and while more work is needed, it begins to look as though vagueness occurs as much or more than precision does, with vagueness being occasionally appropriate. Secondly, considering all their efforts to define fuzzy language, it can be clarified that if any language (phonetics, words, phrases or paragraphs) is left for the imagination, expressing unclear understanding or explanation, it is likely to be fuzziness in language.

\section{B. Categorization of Fuzzy Language}

Fuzzy language is not an ambiguous language, but a phenomenon corresponding to precise language, which expresses the denotative fuzziness and relative concepts of logical expression of words. Compared with accurate language, fuzzy language has higher coverage, greater flexibility and aesthetic value that is increased by the amount of semantic information and is beneficial to the expansion of the readers' imagination. Vagueness of language is one of its intrinsic attributes, which is quite common in literature and in this paper fuzzy language in literature is categorized into the following three types.

\section{Linguistic vagueness}

Vagueness is primarily a semantic phenomenon, and not a pragmatic one, as vagueness cannot always be imputed to language users. Therefore, in translating a literary work, the translator frequently encounters semantic fuzziness and pragmatic fuzziness (Shao: 2007). Kempson (1977) also puts different types of polyvalence on par under the heading "vagueness': (1) "referential vagueness" (e.g., city-town, house-cottage), (2) “indeterminacy of meaning” (e.g., John's book, good), (3) "lack of specification" (e.g., neighbor, do), and (4) "disjunction in the specification of the meaning" (e.g., or). Word meaning is a very complicated part of the process of translation. British scholar Leech (1981) divides meaning into seven types: conceptual meaning, connotative meaning, social meaning, affective meaning, reflective meaning, collocative meaning, and thematic meaning. Take "juvenile" and "teenager" as an example, it can be difficult to distinguish the exact difference between the two words in terms of "social meaning". To distinguish them translators must resort to their "thematic meaning" and "connotative meaning".

In literary works pragmatic vagueness is a common practice, where the author leaves much room for readers to imagine. Bussmann (1996) calls an expression pragmatically vague with respect to certain semantic features which it leaves unspecified: e.g., person is not specified with reference to the features [male] vs [female], [old] vs [young]". Zwicky (1973) states that sister is "vague" between the readings 'older sister' and 'younger sister', but he argues that: neutral and unspecified would also be appropriate terms. The proper process of pragmatic vagueness relieves readers of the trouble of understanding.

\section{Cultural vagueness}

Language used in any works is inseparable from the author's living environment, educational background and their personal experience. That is to say, language is an integral part of culture that includes language, customs, attitudes and values, religion and social structure. Due to the constant influence of various factors, the cultures developed in different regions are sharply different from each other. Therefore, the diversity of language and culture is expressed in the process of each work. Because the language used in each writing is developed in a specific cultural background such culture-rich language will be a big challenge for translators when attaining to fully reproduce the source-text effect. Therefore, translation should be based on comprehending people living in other cultural environments, which in turn will have a significant impact on the accuracy of expression and achievement of communicative purpose.

\section{Rhetorical vagueness}

Although vagueness often occurs unintentionally, it may also be employed as a deliberate rhetorical strategy to avoid dealing with an issue or responding directly to a question. In Emotive Language in Argumentation, Macagno \& Walton (2014) note that vagueness "can also be introduced for the purpose of allowing the speaker to redefine the concept he wishes to use". In Vagueness as a Political Strategy (2013), Giuseppina Scotto di Carlo observes that vagueness is "a pervasive phenomenon in natural language, as it seems to be expressed through nearly all linguistic categories". In short, 
vagueness is an essential feature of language.

\section{CASE ANALYSIS OF DR. ZHA'S DiARY OF FIGHTING THE COVID-19}

Based on the categorization and analysis of fuzzy language above, it is clear that vagueness is a common phenomenon in literature and requires translators to take special heed of in translation.

\section{A. Linguistic Vagueness}

Semantic expression is limited in scope, usually a circular scope with fuzzy edges. Generally, there is a core in the semantic scope, and the periphery of the semantic core belongs to the edge area of the circular semantic scope, which indicates the semantic transition from "precise" to "fuzzy". A "Semantic kernel" represents the original precise meaning of words, which is an objective reflection of the author's thoughts and intents. In the process of translation, it is necessary to compare and analyze the exact lexical meanings, so the translator needs to fully consider the thoughts and emotions that words indicate, and fully understand the language collocation, the cultural background and ethnicity of the source text author.

Source text case 1: 医生办公室的墙壁上贴着“武汉加油”的标语。(Zha: 2020)

Target text case 1: The slogan "Stay strong, Wuhan” is pasted on the wall of the doctor's office.(Ye \& Yang: 2020)

“加油” is ambiguous in Chinese, which can mean “come on", “cheer somebody on”, "tank a car up” or "stay strong”. Of the four senses, "take a car up" is not relevant at all and is removed. Then the differences between the other three are: You say 'Come on' to someone to encourage them to do something they do not much want to do; When you cheer someone on, you shout loudly in order to encourage them. You say "stay strong" to someone who suffers from pain, disease, disaster, etc. As readers of this diary should know that Wuhan is currently experiencing suffering because of COVID-19, it should be translated as "stay strong" in this case to show that the medical staff are trying to encourage Wuhan people and also reflects the optimism as well as the spirit of solidarity amongst Chinese people.

Source text case 2: 任何困难都能克服, 要有勇气, 要有攻坚克难的决心, 团结一致, 以饱满的精神、昂扬的 斗志进入战斗。(Zha: 2020)

Target text case 2: He encouraged us to be courageous and determined to overcome any difficulties and said we should be united and enter the battlefield full of vigor, with a fighting spirit, and with high morale. (Ye \& Yang: 2020)

Literary translation is often influenced by culture-specific expressions so it is not always easy to find the corresponding English terms. In such cases it is necessary to resort to pragmatics to translate in non-equivalent languages, so as to achieve the equivalent effect of the target text as much as possible. In source text case 2 “团结一致”, “饱满的精神”, “昂扬的斗志” are all very tricky expressions, even in Chinese. “团结一致” literally means “united” and "act in accordance" but if both phrases are used in translation, the expression will be somewhat cumbersome. Thus, the expression is condensed to be “united”. In the phrase “饱满的精神”, “精神” does not refer to their spirit or mental state, instead, it means “vigor". So, this phrase is translated as “full of vigor". “昂扬的斗志” is the third phrase that contains semantic vagueness in this sentence, which indicates the medical staff were required to take their position with valiancy, so it is translated as "with a fighting spirit, and with high morale". In source text case 2, Dr. Zha deliberately describes the way the medical staff would take over their new task at Jinyintan Hospital, so translation should reproduce the fearless spirit of the medical staff and the whole sentence is translated as He encouraged us to be courageous and determined to overcome any difficulties and said we should be united and enter the battlefield full of vigor, with a fighting spirit, and with high morale.

Source text case 3: 两个多月来, 我在感动、担忧甚至哽咽中为数批上海交通大学医学院的援鄂医疗队送行, 更通过微信朋友圈关注在湖北、武汉“玩命”的援鄂战友。(Zha: 2020)

Target text case 3: Every time I sent off medical teams from Shanghai Jiao Tong University School of Medicine over the past two months, I was moved to tears and choked with anxiety for their safety. I have since followed WeChat Moments, showing concern for my comrades in-arms who are assisting Hubei in the combat against 2019-nCov, and putting their own lives at risk to do so. (Ye \& Yang: 2020)

In source text case 3, “玩命” is a fantastic expression, which originally means "gamble one's life". However, in this case, it depicts the courageous behavior of medical staff members who would not retreat when faced with the life-threatening risks. To present the image vividly, it is translated as "putting their own lives at risk to do so" to demonstrate the medical staff's noble spirit. In target text case 3, "2019-nCov" is added and translated intentionally like this because the translation of “新冠肺炎” varied as the way WHO addressed it. In other words, prior to Feb, 12 $2^{\text {th }}, 2020$, it was called "2019-nCov" and thereafter it has been addressed "COVID-19".

Source text case 4: 我想, 那段伤痛可能会随着时间的流逝渐渐痊愈, 那段记忆也有可能随着时代的变迁被人 遗忘, 而《日记》中记录的点点滴滴, 一定会唤起我们的记忆。(Zha: 2020)

Target text case 4: As time goes by, the pains experienced in that period may go away and the memories may recede, but the little things recorded in the diary will stay forever. They will never fail to refresh our memory. (Ye \& Yang: 2020)

In source text case 4: “伤痛” and “痊愈” are two vague expressions. “伤痛” literally means one's physical pain, 
which here refers to the mental sufferings that Chinese experienced in fighting the COVID-19. “痊愈” originally indicates recovering from a certain disease but in this case it means that people gradually forgot the unhappy experience. Combining the two expressions, the target text is translated into "the pains experienced in that period may go away" to show the optimistic spirit of Chinese people.

Source text case 5: 1 月 25 日 1：30, 飞机缓缓降落在武汉天河机场, 降落前的细雨在我们出机舱时居然已 经停止, 这似乎预兆着什么。(Zha: 2020)

Target text case 5: At 1:30 a.m. on January 25, the plane landed at Tianhe Airport in Wuhan. It was drizzling before we landed. By the time we disembarked, the rain had stopped. This seemed to be a good sign. (Ye \& Yang: 2020)

Source text case 5 is description of the background in which Dr. Zha arrived in Wuhan with her teammates. By “飞机 缓缓降落在武汉天河机场”, Dr. Zha indicates that the pilot was very careful to ensure the safe and comfortable landing of the plane, thus making the flight a complete success, so this phrase was translated into "the plane landed smoothly at Tianhe Airport in Wuhan”. “这似乎预兆着什么” is the typical embodiment of Chinese vague expression, where readers need to examine Dr. Zha's writing intention and infer between lines. Compared with the previous part "the plane landed" and the drizzle had stopped before they got out of the cabin, it can be inferred that Dr. Zha was suggesting that it was a good sign. Taking into account of Dr. Zha's mission and her confidence of winning the campaign, it is highly likely that it should be considered a positive description, so this sentence is translated as "This seemed to be a good sign." This part of target translation is mainly done through literal translation by using short and simple sentences to convey information, in which the target language is simple and clear, in line with the characteristics of diary writing.

Source text case 6: 武汉的天灰蒙蒙的, 又湿又冷, 空气中似乎笼罩着一丝阴䨪, 这样的天气确实不利于病毒 的灭活。(Zha: 2020)

Target text case 6: It was wet and cold. The sky was grey and shrouded in dense clouds. This weather was not conducive to fighting the virus. (Ye \& Yang: 2020)

Source text case 6 is an example of pragmatic vagueness in that Dr. Zha describes the ordinary weather of Wuhan in late winter by using the vague phrase “阴霾”. “阴霾” means both “dark, gloomy weather” and “suppressing atmosphere”. By “笼罩着一丝阴霧” Dr. Zha suggests that their work was very challenging and they needed all their efforts to fight the virus. In translation, the pragmatic function of “阴䨪” should be taken into account. Luckily, the second half of this case tells the reader that “阴霾” factually refers to the weather. This clarified, the sentence is then regrouped and translated as "It was wet and cold. The sky was grey and shrouded in dense clouds. This weather was not conducive to fighting the virus".

\section{B. Cultural Vagueness}

As mentioned above, cultural vagueness causes readers to have perception difficulties because each writer has a unique understanding of their culture and the way they present their culture in the work is special. Thus, readers who are not familiar with the writer's cultural background sometimes may find it difficult to perceive the writer's writing intention.

Source text case 7: 现在武汉这座城市生病了, 作为共饮长江水的上海人, 我们有责任和义务去帮助他们。(Zha: 2020)

Target text case 7: Unfortunately, Wuhan is now suffering from the COVID-19 pandemic, so we have the responsibility and obligation to help them out. After all, ours is a long friendship, since we in Shanghai and our compatriots in Wuhan all drink out of the same Yangtze River. (Ye \& Yang: 2020)

From the perspective of linguistic aesthetics, the Chinese language pays attention to antithesis and neatness while English is concise and more logical, emphasizing the aesthetic orientation of mathematical relationship. In source text case 7, Dr. Zha creates an image that Wuhan and Shanghai “共饮长江水”, which makes readers feel the image that Wuhan people and Shanghai people are very close to each other since they drink out of the same Yangtze River. This image displayed in her work arouses the reader's empathy and has aesthetic function. To make it easier for English readers to understand why Shanghai medical team had responsibility to help Wuhan people out, we need to take note that “共饮长江水” is translated literally as "since we in Shanghai and our compatriots in Wuhan all drink out of the same Yangtze River". “共饮长江水” also indicates that the two cities have a long-lasting friendship, so “ours is a long friendship" is added to make the translation more sensible.

Source text case 8: 那种“去留肝胆两昆仑”“不破楼兰终不还”的大无畏精神，可歌可泣！(Zha: 2020)

Target text case 8: They are fearless, heroic and stirring, qualities seen in the heroes in Chinese history, who chose not to withdraw in the face of death, and the soldiers in the poems of the Tang Dynasty, who were determined not to return until the enemy in the borderlands was defeated. (Ye \& Yang: 2020)

Source text case 8 expresses strong emotions and depicts two impressive scenes with concise language. With only 26 Chinese characters Dr. Zha quotes two ancient Chinese stories in order to present to readers the heroic spirit of the medical staff. By quoting the story "Tan Sitong" (who sacrificed his life for righteousness after the failure of the reform movement in 1898) and Wang Changling's poem, she conveys rich connotation and praises the amiable and respectable 
spirit of medical team members. "They are fearless, heroic and stirring" is the semantic focus of the whole sentence, which means that the medical staff's fearless spirit is admirable. In the source text, the expressions of “去留肝胆两昆 仓” and “不破楼兰终不还” emphasize the expression of “their fearless spirit”. However, the readers of English-speaking countries may know nothing about the two Chinese household stories. Therefore, the related historical background knowledge is supplemented. This makes reading more comprehensible, while at the same time allowing traditional Chinese culture to be shared with the world. Tan Sitong's name is not so important to English readers. Therefore, in order to understand the gist of Dr. Zha's writing purpose, it is omitted.

Source text case 9: 翻看了朋友圈, 我才知道昨天是年初五迎财神的日子。(Zha: 2020)

Target text case 9: From my WeChat Moments, I realized that yesterday was the fifth day of the first lunar month, when people traditionally prepare a feast to receive an auspicious deity, The God of Fortune. (Ye \& Yang: 2020)

“迎财神”is an important Chinese tradition held on the fifth day of the first lunar month. Dr. Zha creates a literary image of that day to demonstrate how occupied they were as to forget such an important occasion. In literary translation, translators should also pay attention to the fuzziness of literary image because proper image reproduction, in the process of translation, can make the language of the target text highly consistent with the beauty of the image found in the source text. Therefore, to prevent the loss of the artistic nature of the image found in the source text, “昨天是年初五迎 财神的日子” was translated as “yesterday was the fifth day of the first lunar month, when people traditionally prepare a feast to receive an auspicious deity, The God of Fortune". With the supplementation of "an auspicious deity, The God of Fortune", English readers will find it easy to conceive an image of Chinese culture.

Source text case 10: 上海市发改委、上海市粮食和物资储备局给我们送来了很多件军大衣, 让我们这些奋战在 抗疫一线的医护人员感到分外温暖。(Zha: 2020)

Target text case 10: In the afternoon, we received cotton-padded military coats from Shanghai Municipal Development and Reform Commission and the Shanghai Municipal Grain and Material Reserve Bureau, which made us feel especially warm as we fought on the frontline in the battle against COVID-19. (Ye \& Yang: 2020)

“上海市发改委、上海市粮食和物资储备局” are special Chinese cultural terms, which are hard for English readers to perceive. To make it less difficult to understand the terms, they are translated in reference to their respective official English name. “军大衣” is also one of those terms commonly used in China but western readers may find it a big challenge to create a concrete image of it in their minds. Therefore, paraphrase is employed in this case and the term is translated as "cotton-padded military coats" so that western readers can properly construe an image of the coat.

Source text case 11: 从进入武汉的第一天起, 我们医疗队就有女医护人员纷纷剪短了三千烦恼丝。壮士断腕, 战士断发! (Zha: 2020)

Target text case 11: Since we entered Wuhan, some female medical staff in our team had their hair cut short. In ancient times, a vigorous warrior cut off his arm if it was bitten by a poisonous snake. (Ye \& Yang: 2020)

Literary artistic conception can be a scene, a picture and emotional appeal displayed in literary works. It is embodied, through the artistic conception of literary creators, when using concrete images. In source text case 11, “三千烦恼丝” is a term used in Buddhism to refer to one's hair and in this case what the female doctors cut short was clearly their long hair, so in translation, this part is “some female medical staff in our team had their hair cut short." “壮士断腕” is also an ancient Chinese story about a warrior who cut off his arm when it was bitten by a poisonous snake. The story was included in translation, in order to present Chinese culture to western readers so that readers may understand how bold those female medical staff were to cut short their highly-cherished long hair.

\section{Rhetorical Vagueness}

When writers create literary works, they often endow them with personal emotions by using figure of speech, which constitute the fuzzy beauty of literary works. Therefore, when translating literary works, translators should also consider the factors affecting the fuzziness of literary beauty. This requires translators to transplant the literary beauty in the source text accurately, not only to have correct aesthetics and values, but also to go deeper into the literary works, carefully ponder the author's thoughts, maximize the emotional resonance with the original authors, thoroughly analyze the vague beauty of the works, and fully express the emotions expressed in the works to realize the vague beauty of the source texts.

Source text case 12: “历史是最好的教科书，也是最好的清醒剂。”(Zha: 2020)

Target text case 12: “History is the best textbook and it is the best dose of sobriety." (Ye \& Yang: 2020)

Source text case 12 is a metaphor, a typical rhetorical device in Dr. Zha's Diary of Fighting the COVID-19. Demjén \& Semino (2020) hold that, "metaphor involves the perception of similarities or correspondences between unlike entities and processes, so that one can experience, think and communicate about one thing in terms of another - lives as journeys, minds as machines, emotions as external forces, and so on". In other words, metaphors are feature-relevant. In this case, a metaphor is used to compare history as “教科书” and “清醒剂” instead of stating what is actually meant. In translation, the image should be preserved (as much as possible) to fully reproduce the source text effect so that this phrase was translated as "History is the best textbook and it is the best dose of sobriety.".

In target text case 12, “历史是最好的教科书” suggests that if human beings learn from history, they will be wiser. 
In other words, history is likened to be textbooks in this case. Therefore, this part is literally translated as "History is the best textbook", which echoes the Chinese saying "Who knows the history, who knows the future.” The second part "“也 是最好的清醒剂”, expresses another function of history because learning from history gives people a clear mind. Therefore, it is translated literally as "it is the best dose of sobriety". In this part, sobriety functions in the same way as a textbook does.

Source text case 13: 24 日是农历除夕, 年夜饭吃到一半, 就接到了当晚出发去武汉的通知, 这就跟等待楼上的 靴子落地一样, 悬了一天的心总算放下了。(Zha: 2020)

Target text case 13: I was halfway through my family meal on the Lunar New Year's Eve, January 24 ${ }^{\text {th }}$, when the notice arrived, saying that I was to leave for Wuhan that night. I was very relieved that the other shoe had dropped. (Ye \& Yang: 2020)

“农历除夕” is a special occasion in China, for on this day most Chinese people will have family reunion and dinner together. Before Dr. Zha got the final notice, she had already known about the task of aiding Wuhan and the only which remained uncertain was when to set off. So when she finally got the notice, she was relieved. Dr. Zha uses a metaphor to describe her feeling in Chinese: “这就跟等待楼上的靴子落地一样，悬了一天的心总算放下了”. To achieve a similar rhetorical effect, this part was translated literally as "I was very relieved that the other shoe had dropped" to suggest that the coming notice was indeed inevitable.

Source text case 14: 因为我们有中国共产党的领导，有社会主义制度，有政治优势，有“全国一盘棋”的优势， 我们有信心打赢这场仗。(Zha: 2020)

Target text case 14: We should have confidence, because we have the unified leadership of the Communist Party of China, the socialist system, the political advantages, and the advantage of a coordinated national response. (Ye \& Yang: 2020)

Dr. Zha places her emotional factors into the description of this case, and integrates the parallel phrases organically to realize the integrity and coordination of the whole expression. Therefore, it is necessary for translators to deeply understand the artistic conception of the source text because only by truly understanding the artistic conception of the source text can the target text perfectly reproduce the artistic conception of the source text, achieve the best artistic effect and achieve the writing purpose of Dr. Zha. In this case, the key part is that "we" should have confidence because "we" have so many advantages, such as the leadership of the Communist Party of China, socialist system and political advantage. By using this metaphor of “全国一盘棋” Dr. Zha shows her confidence of winning the campaign. But this phrase is hard for western readers to understand in that it is a typical Chinese expression. To make it more comprehensible, it is revised as "unified" and combined with "leadership of the Communist Party of China" so that western readers will know that with the strong leadership of CPC, the virus will soon be defeated.

Source text case 15: 一方有难, 八方支援。上海是我们的坚强后盾。虽然条件艰苦, 但是相信在上海乃至全国 人民的支持下，我们一定能够不辱使命，不负重托，打赢这场疫情防控的战役，践行新时期白衣战士的神圣使 命。(Zha: 2020)

Target text case 15: When disaster struck, help came from all sides. Shanghai was our benefactor. Though the conditions were difficult in Wuhan, I believed that with the support of Shanghai and the rest of the country, we would succeed in carrying out the assignment and doing what was expected. We would win this battle with COVID-19 and fulfill the sacred mission of white-coat "soldiers" in the new era. (Ye \& Yang: 2020)

Source text case 15 sees that Dr. Zha shows her determination of fighting the COVID-19 by using “一方有难，八方 支援”, “坚强后盾”, “不辱使命”, “不负重托” and “神圣使命”, in which four-character phrases are used to strengthen the power of her words. In addition, she uses two metaphors to make her expression more vivid: one is “坚强后盾” and the other “白衣战士”. In translation, “坚强后盾” is translated as “benefactor” to express her confidence in Shanghai municipal government and “白衣战士” is translated as “white-coat 'soldiers” to demonstrate their courage with quotation mark. The two phrases “不辱使命”, “不负重托” are abstract so in translation, they are materialized as "succeed in carrying out the assignment and doing what was expected". In this way, English readers may find it easy to comprehend Dr. Zha's writing purpose.

Source text case 16: 回到酒店, 晚上 7 ：30 将举行医疗队第一次党员大会, 主旨是“不忘初心，牢记使命”“只 争朝夕, 不负韶华”。(Zha: 2020)

Target text case 16: Returning to the hotel, I was told that the first medical team's Party meeting would be held at 7:30 p.m. The theme of the meeting was "remaining true to our original aspirations and keeping our mission firmly in mind" and "seize the day and live it to the full." (Ye \& Yang: 2020)

Source text case 16 is another example of four-character expressions in Chinese, which are frequently used on special occasions in China. “不忘初心，牢记使命” is a popular proposal to all walks of life in contemporary China, aiming to make people stick to their original aspirations and stay true to their goals. “只争朝夕，不负韶华” is used to show to the readers how urgent their mission is. Therefore, the translation must reflect Dr. Zha's original purpose and the target text is "remaining true to our original aspirations and keeping our mission firmly in mind" and "seize the day and live it to the full". 


\section{CONCLUSION}

Fuzzy language is a form of language entity and many expressions in language entity fuzzy characteristics. In the process of literature translation, it is necessary to fully study the fuzzy denotation of linguistic expressions to ensure that the target texts achieve corresponding language functions and realize good aesthetic effects. Therefore, it is very important to handle vague language properly, especially for works with cultural differences. Grasping and understanding vague language accurately is conducive to ensuring the high quality of translation and effectively conveying various types of information.

In conclusion, it is evident that when theoretic fuzzy literary analysis is applied in the process of translation, it can not only provide readers with a better reading experience, but also help to reproduce and deepen the beauty in the source text.

Further studies can focus on quantitative analysis of the process of fuzzy language to see how translators consciously or unconsciously convey the source text information into the target language and how the aesthetic effect is achieved by employing the theoretic analysis.

\section{ACKNOWLEDGEMENTS}

This research has been partially supported by the Research Project of Higher Educational Teaching Reform of Zhejiang Province under grant No. jg20190506, the Research Project of Higher Educational Teaching Reform of Shaoxing under grant No. SXSJG201803 and A New Approach to Grammar Teaching under the Content Based Instruction of English Novel Reading under grant No. kg2013473.

\section{REFERENCES}

[1] Baker, M. \& Saldanha, G. (2020) Routledge Encyclopedia of Translation Studies. London and New York: Taylor\& Francis Group.

[2] Bussmann, H. (1996) Routledge dictionary of language and linguistics. Trans, and eds. G. Trauth \& K. Kazzazi. London: Routledge.

[3] Carlo, G. S. d. (2013) Vagueness as a Political Strategy: Weasel Words in Security Council Resolutions Relating to the Second Gulf War. Cambridge: Cambridge Scholars Publishing.

[4] Channell, J. (2000). Vague Language. Shanghai: Shanghai Foreign Language Education Press.

[5] Demjén, Z., \& Semino, E. (2020) Metaphor, Metonymy and Framing in Discourse. In A. De Fina \& A. Georgakopoulou (Eds.), The Cambridge Handbook of Discourse Studies (Cambridge Handbooks in Language and Linguistics. Cambridge: Cambridge University Press.

[6] Jakobson, R. (1960/1988). 'Linguistics and Poetics', in D. Lodge (ed.) Modern Criticism and Theory. Harlow: Longman.

[7] Kempson, R. M., and Cormack, A. (1981). “Ambiguity and Quantification.” Linguistics and Philosophy 4. 2, $259-309$.

[8] Leech, G. (1981). The Study of Meaning. $2^{\text {nd }}$ ed. Harmondsworth: Penguin Books.

[9] Macagno, F., \& Walton, D. (2014). Emotive language in argumentation. Cambridge: Cambridge University Press.

[10] Peirce, C. S. (1902). Vagueness, in Baldwin, M. Dictionary of Philosophy and Psychology II, London: Macmillan.

[11] Shao, L. (2007). The Gains and Losses of Fuzzy Language in Intercultural Communication: A Case Study of The Da Vinci Code and Its Two Chinese Versions. Foreign Literature Studies.4, 97-104.

[12] Ullmann, S. (1962). Semantics: an Introduction to the Science of Meaning. Oxford: Basil Blackwell.

[13] Ye, X.G., \& Yang, A.J. (2020). Dr. Zha's Diary of Fighting the COVID-19(English version). St. Coquitlam, BC: Naturalogic.

[14] Zadeh, L. (1965). Fuzzy Sets. Information and Control. 8, 338-353.

[15] Zha, Q.F. (2020). Dr. Zha's Diary of Fighting the COVID-19(Chinese version). Shanghai: Shanghai Jiao Tong University Press.

[16] Zwicky, A. M. (1973). Review article of Jan G. Kooij. Ambiguity in natural language: An investigation of certain problems in its linguistic description. Lingua. 32, 95-118.

\footnotetext{
Aijun Yang is an associate professor of language pedagogy and translation at Zhejiang Yuexiu University who obtained his MA from Shanghai International Studies University, China. His academic interests include foreign language teaching and applied translation.
} 